\title{
Tradução e Adaptação Transcultural do Instrumento de Avaliação do Ensino Médico nas Desordens Musculoesqueléticas
}

\author{
Translation and Transcultural Adaptation \\ of the Instrument of Evaluation of Medical \\ Education in Musculoskeletal Disorders
}

Lucas Augusto Carvalho e Raso Ubiratan Brum de Castrol

\section{PALAVRAS-CHAVE}

- Educação Médica.

- Tradução.

- Questionário.

- Sistema Musculoesquelético.

- Estudos de Validação.

\begin{abstract}
RESUMO
As desordens do sistema musculoesquelético representam entre 10-25\% do motivo das consultas na atenção primária, mas apenas um pequeno percentual do currículo da graduação é dedicado ao estudo desse assunto. Assim, é necessário desenvolver instrumentos objetivos para avaliar essa deficiência na escola médica. O questionário de Freedman e Bernstein é uma ferramenta validada internacionalmente para avaliação dos conhecimentos médicos básicos sobre as desordens musculoesqueléticas e, consequentemente, do ensino durante a formação médica. O objetivo deste estudo foi desenvolver uma versão da escala em língua portuguesa, validada e adaptada transculturalmente para a população brasileira. A tradução e adaptação transcultural do questionário foram conduzidas seguindo as etapas de tradução inicial, retrotradução, composição de uma versão pré-final e seu teste, sendo realizadas as alterações necessárias após essa última fase e a elaboração do modelo final do instrumento. A etapa de teste da versão pré-final consistiu na sua aplicação ao público-alvo da pesquisa - 15 estudantes do último semestre de Medicina. Cada indivíduo respondeu às perguntas do inquérito e, em seguida, foi entrevistado para se analisar o que ele entendeu que era esperado em cada item do questionário. Tanto a interpretação da questão quanto a resposta foram exploradas. Houve dificuldade de compreensão em duas questões, tendo sido preciso substituir alguns termos para facilitar a assimilação. Após as alterações, não houve impedimentos ao entendimento do instrumento final pelos participantes. A validação de conteúdo foi avaliada por um painel de especialistas, que considerou apropriados os termos e a abrangência do questionário traduzido. Essa apreciação foi realizada após o teste final e nenhuma alteração foi recomendada. O questionário encontra-se traduzido para a língua portuguesa, apresentando equivalência semântica, idiomática, conceitual e cultural com o original. Recomenda-se seu uso para a avaliação do ensino das desordens musculoesqueléticas nas escolas de Medicina do País, possibilitando uma comparação do currículo ortopédico brasileiro com os padrões internacionais.
\end{abstract}




\section{KEY-WORDS}

- Medical Education.

- Translating.

- Surveys and Questionnaires.

- Musculoskeletal System.

- Validation Studies.

\begin{abstract}
Disorders of the musculoskeletal system represent between 10-25\% of the reasons for consultations in primary care, however, only a small percentage of the undergraduate curriculum is dedicated to the study of this subject. Thus, it is necessary to develop objective instruments to assess this deficiency in medical schools. The Freedman and Bernstein questionnaire is an internationally validated tool for assessing basic medical knowledge of musculoskeletal disorders and, consequently, evaluate medical training. The objective of this study was to develop a version of the scale in the Portuguese language, validated and adapted transculturally for the Brazilian population. Transcultural translation and adaptation of the questionnaire was conducted following the steps of initial translation, backtranslation, composition of a pre-final version and its test, making the necessary changes after this last phase and development of the final model of the instrument. The pre-final version was applied to the target audience of the research - 15 students in the last semester of Medicine. Each individual answered the questions from the survey and was then interviewed to analyze their understanding of what was expected in each item of the questionnaire. Both the interpretation of the question and the response were explored. There were difficulties in understanding two questions, making it necessary to substitute some terms to facilitate assimilation. After the changes, there were no impediments to the participants' understanding of the final instrument. Content validation was assessed by a panel of experts who considered the terms and scope of the translated questionnaire appropriate. This assessment was made after the final test and no change was recommended. Thus, the questionnaire is translated into the Portuguese language, presenting semantic, idiomatic, conceptual and cultural equivalence with the original. Its use is recommended for the evaluation of the teaching of musculoskeletal disorders in the country's medical schools, allowing a comparison of the Brazilian orthopedic curriculum with international standards.
\end{abstract}

Recebido em: 4/11/18

Aceito em: 17/12/18

\section{INTRODUÇÃO}

As desordens do sistema musculoesquelético apresentam alta representatividade na prática clínica, contabilizando entre $10 \%$ e $25 \%$ do motivo das consultas na atenção primária ${ }^{1-4}$. Reconhecendo essa importância e visando aumentar a conscientização sobre esse tema, a Organização Mundial da Saúde (OMS) declarou o período de 2000 a 2010 como a Década do Osso e da Articulação ${ }^{5}$. Nesse contexto, uma base sólida de conhecimentos em medicina ortopédica deve ser adquirida durante a formação na graduação em Medicina e refinada durante a residência médica. No entanto, apenas um pequeno percentual do currículo da graduação é dedicado ao estudo das desordens musculoesqueléticas. No Brasil, mais da metade das escolas médicas mostraram uma insignificante presença de Ortopedia em seu programa, inserida apenas dentro da Cirurgia como discussão de casos no modelo Problem Based Learning ${ }^{6}$.

Em 1997, Freedman e Bernstein ${ }^{7}$ desenvolveram uma avaliação para testar os conhecimentos básicos nas desordens musculoesqueléticas que todo médico deveria dominar. $\mathrm{O}$ tes- te foi validado por 124 preceptores de programas de residência nos Estados Unidos, que julgaram as questões de acordo com sua relevância e recomendaram uma nota de corte de 73,1\%. No seu estudo original na Filadélfia, 85 médicos residentes em Ortopedia foram avaliados no primeiro dia de sua formação na especialidade, sendo que $70(82 \%)$ deles não atingiram a nota mínima.

Desde então, o mesmo estudo já foi realizado em outras instituições e países ${ }^{8-10}$, incluindo a Harvard Medical School ${ }^{11}$ e a Finders University, na Austrália ${ }^{12}$.

Na literatura em língua portuguesa não foi identificado nenhum questionário que avalie o ensino das desordens musculoesqueléticas durante a formação médica. Para possibilitar a investigação da magnitude deste problema no cenário brasileiro, faz-se necessária a tradução, adaptação transcultural e validação para a língua portuguesa do questionário de Freedman e Bernstein, sendo este o objetivo do presente trabalho. 


\section{MÉTODOS}

A tradução e a adaptação transcultural do questionário foram realizadas de acordo com as etapas padronizadas por Beaton et al. ${ }^{13} \mathrm{e}$ Guillemin et al. ${ }^{14}$ (Figura 1).

Figura 1

Representação esquemática do protocolo usado para tradução e adaptação cultural do "Freedman and Bernstein Questionnaire"

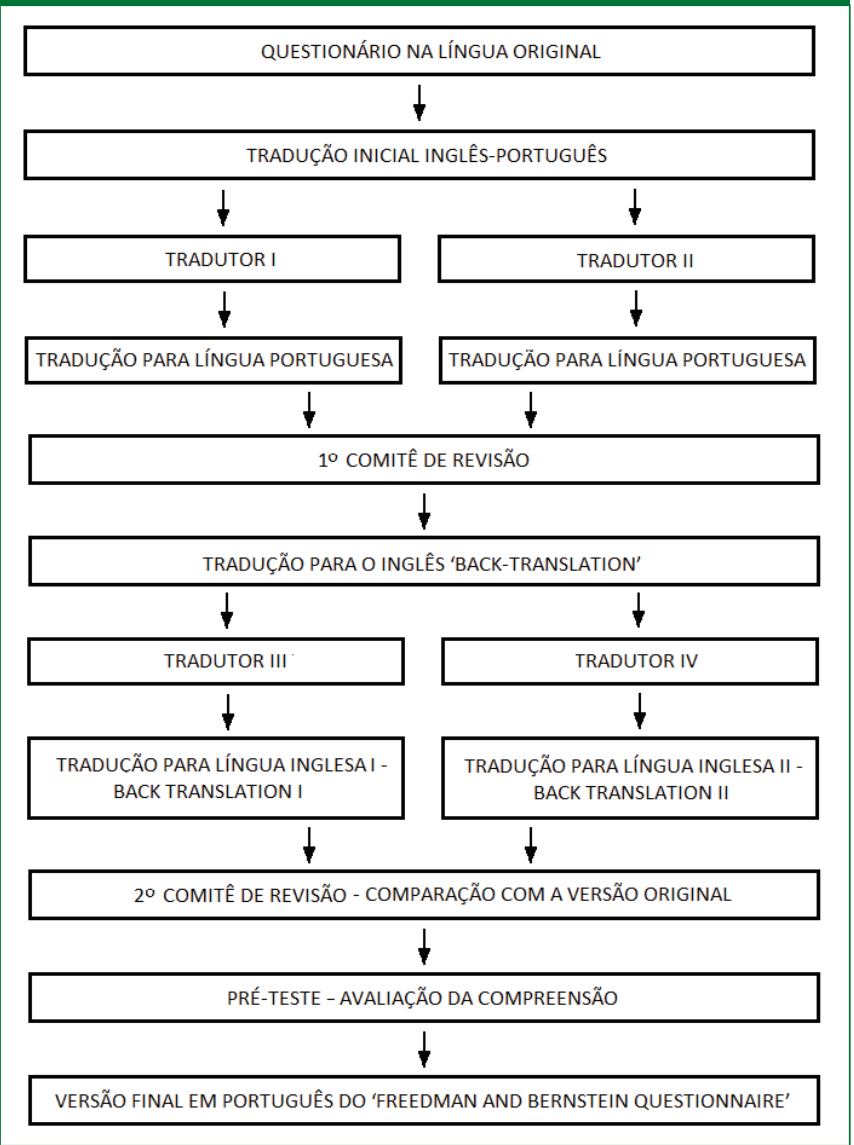

A etapa inicial foi a tradução do questionário original em inglês para o português, realizada de maneira independente por dois indivíduos cuja língua materna é a língua portuguesa e que possuem fluência na língua inglesa. $\mathrm{O}$ tradutor I era da área médica, enquanto o tradutor II foi considerado leigo (Quadro 1).

Após avaliação pelo primeiro comitê de revisão e elaboração da primeira versão em português, a tradução retrógrada para o inglês (back-translation) foi realizada por dois indivíduos cuja língua materna é o inglês e que não tinham conhecimento da versão original do questionário. $\mathrm{O}$ tradutor III era da área médica, enquanto o tradutor IV foi considerado leigo.

O segundo comitê de revisão é crucial para se alcançar a equivalência transcultural, sendo seu objetivo consolidar to- das as versões do questionário e elaborar a versão considerada pré-final, ou consenso, já que ela ainda poderia passar por alterações após as avaliações práticas. Nesse ponto, eles dispunham de todo o material elaborado até o momento e deveriam se certificar de que ocorre equivalência entre o original e a tradução pré-final em quatro áreas: equivalência semântica, idiomática, experiencial e conceitual ${ }^{15}$.

Os comitês de revisão foram compostos por dois médicos ortopedistas pesquisadores com conhecimento do questionário original e domínio linguístico de ambos os idiomas.

A etapa final é o pré-teste, que consistiu na aplicação do questionário consenso ao público-alvo da pesquisa - 15 estudantes do último semestre de Medicina. Cada indivíduo respondeu às perguntas do inquérito e, em seguida, foi entrevistado para se analisar o que ele entendeu que era esperado em cada item do instrumento de avaliação. Tanto a interpretação da questão quanto a resposta foram exploradas.

O presente estudo foi aprovado pelo Comitê de Ética em Pesquisa (Coep) da Faculdade de Medicina da Universidade Federal de Minas Gerais e está em conformidade com o a Resolução 466/12 - CAAE no 17817813.2.0000.5149. Todos os participantes foram orientados sobre os fundamentos do estudo e assinaram o Termo de Consentimento Livre e Esclarecido. Os autores do questionário original foram consultados e autorizaram a tradução do instrumento para a língua portuguesa.

\section{RESULTADOS}

No teste da versão pré-final em português, que visava avaliar a compreensão do público-alvo, houve dificuldade de compreensão na questão 5 em relação à palavra "quebra" no contexto de lesão da pele. A opção pelo modelo de entrevista durante o pré-teste possibilitou clarificar o significado para os participantes, sendo o termo substituído por "ruptura".

Além disso, na questão 25, ficou-se em dúvida se a frase "o músculo que controla a rotação externa" se referia ao músculo agonista ou antagonista do movimento, de modo que se optou por alterar a expressão para "o músculo que realiza a rotação externa".

Após o teste final, não houve impedimentos ao entendimento do instrumento pelos participantes. A validação de conteúdo é definida como a extensão para a qual uma medida reflete o domínio específico pretendido do conteúdo. Pode ser avaliada por um painel de especialistas, que se concentra em revisar e decidir se os termos utilizados no questionário traduzido são abrangentes e apropriados. Essa apreciação foi realizada após o teste final e nenhuma alteração foi recomendada. Assim, esta versão pode ser considerada adequada e utilizada como definitiva (Quadro 2).

O questionário na versão final encontra-se no Anexo 1, e as respostas no Anexo 2. 


\section{QUADRO 1 \\ Tradução do questionário "Freedman and Bernstein Musculoskeletal Examination" \\ Versão original \\ Tradução 1 Tradução 2} mined for?

\section{2. (Q) What is a compartment syndrome?}

3. (Q) Acute septic arthritis of the knee may be differentia-

ted from inflammatory arthritis by which laboratory test?

4. (Q) A patient dislocates his knee in a car accident. What

structure(s) is/are at risk for injury and therefore must be evaluated?

5. (Q) A patient punches his companion in the face and 5. Um paciente soca seu companheiro no rosto e apresenta sustains a fracture of the 5 th metacarpal and a $3 \mathrm{~mm}$ break fratura do $\mathrm{V}$ metacarpo e um corte de $3 \mathrm{~mm}$ na pele sobre in the skin over the fracture. What is the correct treatment, and why?

6. (Q) A patient comes to the office complaining of low back pain that wakes him up from sleep. What two diagnoses are you concerned about?

7. (Q) How is compartment syndrome treated?

8. (Q) A patient lands on his hand and is tender to pal- 8. Um paciente cai apoiado em sua mão e apresenta dor pation in the 'snuff box' (the space between the thumb à palpação na tabaqueira anatômica (o espaço entre o exextensor and abductor tendons). Initial radiographs do tensor longo do polegar e os tendões abdutores). As ranot show a fracture. What diagnosis must be cons deve ser considerado?

9. (Q) A 25-year-old man is involved in a motor vehicle accident. His left limb is in a position of flexion at the knee and the hip, with internal rotation and adduction of the hip. What is the most likely diagnosis?

10. (Q) What nerve is compressed in carpal tunnel syndrome?

11. (Q) A patient had a disc herniation pressing on the 5th lumbar nerve root. How is motor function of the 5 th lumbar nerve root tested?

12. (Q) How is motor function of the median nerve teste in the hand?

13. (Q) A 12-year-old boy severely twists his ankle. Ra- 13. Um garoto de 12 anos torce severamente seu tornozelo. diographs show only soft-tissue swelling. He is tender As radiografias mostram apenas inchaço dos tecidos moat the distal aspect of the fibula. What are two possible les. Apresenta dor no terço distal da fíbula. Quais são doi diagnoses?

14. (Q) A patient presents with new-onset low back pain. Under what conditions are plan radiographs indicated? Please name five (example: history of trauma)

14. Um paciente apresenta dor lombar de início recente.

15. (Q) A patient has a displaced fracture near the fibula neck. What structure is at risk of injury?

16. (Q) A 20-year-old injured his knee while playing football. You see him on the same day, and he has a knee effusion. An aspiration shows frank blood. What are the three most common diagnoses?

17. (Q) What are the five most common sources of cancer metastases to bone?

18. (Q) Name two differences between rheumatoid arthritis and osteoarthritis.

19: (Q) Which malignancy may be present in bone yet typically is not detected with a bone scan?

20. (Q) What is the function of the normal anterior cruciate ligament at the knee?

21. (Q) What is the difference between osteoporosis and 21. Qual a diferença entre osteoporose e osteomalácia? osteomalacia?

22. (Q) In elderly patient, displaced fracture of the femoral 22. Em pacientes idosos, fraturas deslocadas do colo do neck are typically treated with joint replacement, whereas fêmur são tipicamente tratadas com substituição articular fractures near the trochanter are treated with plates and enquanto as fraturas próximas ao trocanter são tratadas screws. Why?

23. (Q) What muscle(s) is/are involved in lateral epicondylitis (tennis elbow)?

24. (Q) Rupture of the biceps at the elbow results in weakness of both elbow flexion and

25. (Q) What muscle(s) control(s) external rotation of the humerus with the arm at the side? 1. Qual problema con 2. O que é síndrome compartimental?

9. Um homem de 25 anos se envolve em um acidente automobilístico. Seu membro inferior esquerdo está em posição de flexão do joelho e quadril, com rotação interna e adução do quadril. Qual é o diagnóstico mais provável?

10. Qual nervo é comprimido na síndrome do túnel do carpo?

11. Um paciente tem uma hérnia de disco comprimindo a raiz do $5^{\circ}$ nervo lombar. Como é testada a função motora da raiz do $5^{\circ}$ nervo lombar?

12. Como é testada a função motora do nervo mediano na mão? possíveis diagnósticos? Em quais condições as radiografias simples estão indicadas? Por favor, enumere cinco (exemplo: história de trauma).

15. Um paciente tem uma fratura deslocada próximo ao colo da fíbula. Qual estrutura está em risco de lesão?

16. Um paciente de 20 anos machucou seu joelho enquanto jogava futebol. Você o examina no mesmo dia e ele tem um derrame articular no joelho. $\mathrm{O}$ aspirado mostra sangramento franco. Quais são os três diagnósticos mais comuns?

17. Quais são as cinco fontes mais comuns de câncer metastático para o osso?

18. Cite duas diferenças entre artrite reumatoide e osteoartrose.

19. Qual malignidade pode estar presente no osso, mas, tipicamente, não é detectada em uma varredura óssea?

20. Qual a função normal do ligamento cruzado anterio do joelho?

1. Para qual prob

recém-nascidos?

2. O que é uma síndrome compartimental?

3. Artrite séptica aguda do joelho pode ser diferenciada de artrite inflamatória por meio de qual teste laboratorial? 4. Um paciente deslocou seu joelho em um acidente de carro. Qual(is) estrutura(s) corre(m) risco de lesão e deve(m), portanto, ser avaliada(s)?

5. Um paciente atinge seu companheiro com um soco na face e sofre uma fratura do $5^{\circ}$ metacarpo e uma quebra de $3 \mathrm{~mm}$ na pele sobre a fratura. Qual é o tratamento correto e por quê?

6. Um paciente chega ao consultório reclamando de lombalgia que o acorda durante o sono. Quais dois diagnósticos o preocupam?

7. Como é o tratamento da síndrome compartimental?

8. Um paciente cai sobre a mão e é sensível a apalpação na tabaqueira anatômica (espaço entre os tendões extensor do dedão e abdutor). Radiografias iniciais não exibem uma fratura. Qual diagnóstico deve ser considerado?

9. Um homem de 25 anos se envolve em um acidente de veículo motorizado. Seu membro esquerdo está em posição de flexão no joelho e no quadril, com rotação interna e adução do quadril. Qual é o diagnóstico mais provável? 10. Qual nervo é comprimido na síndrome do túnel carpal?

11. Um paciente tem uma hérnia de disco pressionando a raiz do $5^{\circ}$ nervo lombar. Como se testa a função motora da raiz do $5^{\circ}$ nervo lombar?

12. Como é testada a função motora do nervo mediano na mão?

13. Um menino de 12 anos torce gravemente seu tornozelo. Radiografias exibem apenas inchaço de tecido mole. Ele apresenta sensibilidade no aspecto distal da fíbula. Quais são dois possíveis diagnósticos?

14. Um paciente apresenta uma nova ocorrência de lombalgia. Em quais condições radiografias simples são indicadas? Favor citar cinco (por exemplo: histórico de trauma).

15. Um paciente tem uma fratura com desvio próximo ao colo da fíbula. Qual estrutura está sob risco de lesão?

16. Um jovem de 20 anos machucou seu joelho jogando futebol. Você o vê no mesmo dia, e ele tem uma efusão do joelho. Uma aspiração mostra presença de sangue. Quais são os três diagnósticos mais comuns?

17. Quais são as cinco fontes de metástases ósseas mais comuns?

18. Nomeie duas diferenças entre a artrite reumatoide a osteoartrose

19. Qual malignidade pode estar presente no osso, e aind assim geralmente não é detectada na cintilografia óssea?

20. Qual é a função do ligamento cruzado anterior normal no joelho?

21. Qual a diferença entre a osteoporose e a osteomalácia?

22. Em pacientes idosos, fraturas com desvio do pescoço do fêmur são geralmente tratadas com prótese de articulação, enquanto fraturas próximas ao trocanter são tratadas com placas e parafusos. Por quê? com placas e parafusos. Por quê?

23. Qual(is) músculo(s) está(ão) envolvido(s) na epicondilite lateral (cotovelo de tenista)?

lite lateral (cotovelo de tenista)?

24. A ruptura do bíceps no cotovelo resulta em fraqueza tanto da flexão do cotovelo quanto de? tanto da flexão do cotovelo quanto da

25. Qual(is) músculo(s) controla(m) a rotação externa do úmero com o braço na lateral? 
Retrotradução 1

1. What common problem should all newborns be examined for?

2. What is compartment syndrome?

Retrotradução 2

Versão de consenso

3. Through which laboratory test can acute septic arthritis 3 . Acute septic arthritis of the knee can be distinguished of the knee be differentiated from inflammatory arthritis? from inflammatory arthritis by which laboratory test?

4. A patient dislocates his knee in a car accident. What 4. A patient dislocated his knee in a car accident. Which structure(s) is(are) at risk of injury and therefore must be structure(s) is/are at risk of injury and therefore must be evaluated?

5. A patient punches his companion in the face and suffers a fracture of the 5 th metacarpal and a $3 \mathrm{~mm}$ break in the skin over the fracture. What is the correct treatment and why?

6. A patient comes to the office complaining of low back pain that wakes him up from sleep. What two diagnoses are you concerned about?

7. How is compartment syndrome treated? 5. A patient hit his companion with a punch in the face and suffers a fracture of the 5th metacarpal and a $3 \mathrm{~mm}$ break in the skin over the fracture. What is the correct treatment, and why?

1. Para qual problema comum se deve examinar todos os recém-nascidos?

2. O que é síndrome compartimental?

3. Artrite séptica aguda do joelho pode ser diferenciad de artrite inflamatória por meio de qual teste laboratorial?

4. Um paciente deslocou seu joelho em um acidente de carro. Qual(is) estrutura(s) correm(m) risco de lesão e deve $(\mathrm{m})$, portanto, ser avaliada $(\mathrm{s})$ ?

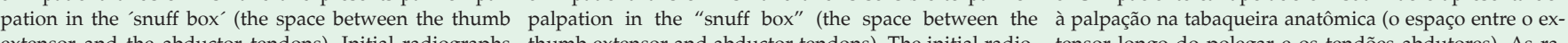
extensor and the abductor tendons). Initial radiographs show no fracture. What diagnosis must be considered?

thumb extensor and abductor tendons). The initial radiographs don't show fracture. What diagnosis should be considered?

5. Um paciente atinge seu companheiro com um soco na face e sofre fratura do $5^{\circ}$ metacarpo e uma quebra de 3 $\mathrm{mm}$ na pele sobre a fratura. Qual é o tratamento correto e por quê?

pain that wakes him up during sleep. What two diagnose are you concerned about?

7. How is the treatment of compartment syndrome? balgia que o acorda durante o sono. Quais dois diagnósticos o preocupam?

7. Como é o tratamento da síndrome compartimental? diografias iniciais não mostram fratura. Qual diagnóstico deve ser considerado?

9. A 25-year-old man is involved in a car accident. His left 9. A 25 year old man was involved in an automobile ac- 9. Um homem de 25 anos se envolve em um acidente aulower limb is in a position of flexion at the knee and hip, cident. His left leg is flexed at the knee and the hip, with tomobilístico. Seu membro inferior esquerdo está em powith internal rotation and hip adduction. What is the most internal rotation and adduction of the hip. What is the likely diagnosis? most likely diagnosis?

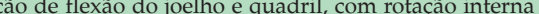
adução do quadril. Qual é o diagnóstico mais provável?

10. What nerve is compressed in carpal tunnel syndrome? 10. What nerve is compressed in carpal tunnel syndrome? 10. Qual nervo é comprimido na síndrome do túnel de carpo?

11. A patient has a herniated disc compressing the root of 11 . A patient has a disc herniation compressing the 5 th 11 . Um paciente tem uma hérnia de disco comprimindo a the 5 th lumbar nerve. How is motor function of the 5 th lumbar nerve root. How is motor function of the 5 th lumlumbar nerve root tested? bar nerve root tested? raiz do $5^{\circ}$ nervo lombar. Como é testada a função motora da raiz do $5^{\circ}$ nervo lombar?

12. How is motor function of the median nerve tested in 12 . How is motor function of the median nerve in the hand 12 . Como é testada a função motora do nervo mediano the hand? tested? na mão?

13. A 12-year old boy severely twists his ankle. Radiogra- 13. A 12 year-old severely twists his ankle. Radiographs 13 . Um garoto de 12 anos torce severamente seu tornozelo. phs show only soft-tissue swelling. Presents tenderness at show only soft-tissue swelling. he shows pain in the distal As radiografias mostram apenas inchaço dos tecidos mothe distal aspect of the fibula. What are the two possible aspect of the fibula. What are two possible diagnoses? diagnoses?

14. A patient presents with new-onset low back pain. Under what conditions are plain radiographs indicated? Please name five (example: history of trauma)

14. A patient shows new-onset of low back pain. In which conditions are plain radiographs indicated? Please nam five (example: history of trauma). possíveis diagnósticos?

14. Um paciente apresenta uma nova ocorrência de lombalgia. Em quais condições radiografias simples são indicadas? Favor citar cinco (por exemplo: histórico de trauma)

15. A patient has a displaced fracture near the fibula neck. 15. A patient has a displaced fracture near the fibular neck. What structure is at risk of injury? What structure is at risk of injury?

16. A 20-year old injured his knee playing soccer. You see 16. A 20 year old injured his knee playing football. You see him on the same day and he has a knee effusion. An as- him the same day, and he has a knee effusion. An aspirapiration shows the presence of blood. What are the three most common diagnoses?

17. What are the five most common sources of bone metastases?

tion shows frank blood. What are the three most common diagnoses?

18. Name two differences between rheumatoid arthritis 18. Name two differences between rheumatoid arthritis and osteoarthritis

17. What are five most common sources of bone metastasis?

15. Um paciente tem uma fratura com desvio próxima ao colo da fíbula. Qual estrutura está sob risco de lesão?

16. Um jovem de 20 anos machucou seu joelho jogando futebol. Você o vê no mesmo dia, e ele tem uma efusão do joelho. Uma aspiração mostra presença de sangue. Quais são os três diagnósticos mais comuns?

17. Quais são as cinco fontes de metástases ósseas mais comuns? and osteoporosis.

18. Cite

19. What malignancy may be present in the bone but is 19 . Which malignancy may be present in the bone, but tytypically not detected with a bone scan? pically is not detected in a bone scan?

20. What is the function of the normal anterior cruciate 20. What is the function of the normal anterior cruciate ligament at the knee?

21. What is the difference between osteoporosis and teomalacia? ligament at the knee?

19. Qual malignidade pode estar presente no osso, mas, tipicamente, não é detectada em uma varredura óssea?

20. Qual é a função do ligamento cruzado anterior norma no joelho?

21. What is the difference between osteoporosis and os- 21. Qual a diferença entre osteoporose e osteomalácia? teomalacia?

22. In older patients, displaced fractures of the femoral 22. In elderly patients, displaced femoral neck fractures 22. Em pacientes idosos, fraturas deslocadas do colo do neck are typically treated with joint replacement, while are typically treated with joint replacement, whereas fêmur são tipicamente tratadas com substituição articular fractures near the trochanter are treated with plates and fractures near the trochanter are treated with plates and screws. Why? screws. Why? com placas e parafusos. Por quê?

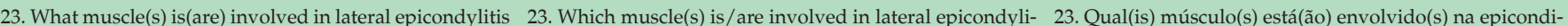
(tennis elbow)? tis (tennis elbow)? lite lateral (cotovelo de tenista)?

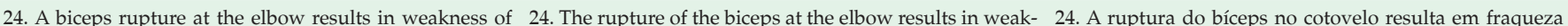
both elbow flexion and ___ ? ness of both elbow flexion and? tanto da flexão do cotovelo quanto de?

25. What muscle(s) control(s) external rotation of the hu- 25. Which muscle(s) control(s) the external rotation of the 25. Qual(is) músculo(s) controla(m) a rotação externa do merus with the arm at the side? úmero com o braço na lateral? 


\section{DISCUSSÃO}

O instrumento "Freedman and Bernstein Questionnaire" foi traduzido e adaptado adequadamente de acordo com os padrões de adaptação cultural, não sendo identificadas dificuldades no processo de compreensão das questões. As entrevistas de debriefing e o retorno dos especialistas sugerem que a nova versão linguística tem validade de conteúdo correspondente ao questionário original.

A adaptação transcultural procura assegurar o desenvolvimento de um instrumento adaptado que seja equivalente ao instrumento original e que possa ser usado pela maioria da população-alvo ${ }^{16}$. Duas traduções independentes foram realizadas nos estágios iniciais de tradução e tradução retrógrada, o que permite a detecção de erros e interpretações divergentes de itens ambíguos na versão em inglês ${ }^{17}$.

No estudo original na Filadélfia, Freedman e Bernstein ${ }^{7}$ utilizaram o questionário para avaliar 85 residentes no início do seu ano de pós-graduação. Setenta (82\%) dos residentes foram reprovados no exame de competências básicas do sistema musculoesquelético. Al-Nammari et al. ${ }^{18}$, em Londres, avaliaram 112 junior doctors no final dos dois anos de estágio prático. Cento e dois $(91,1 \%)$ não obtiveram a nota mínima no mesmo exame $^{18}$. De posse de resultados objetivos, é possível avaliar o currículo interno de cada curso de Medicina e propor mudanças em sua estrutura, equilibrando deficiências no ensino. Portanto, recomenda-se a aplicação do questionário em estudantes do último semestre do percurso acadêmico.

O estudo é limitado pelo pequeno número de entrevistados. Nova pesquisa, já em andamento, permitirá a validação estatística do instrumento e a comparação dos resultados locais com os parâmetros internacionais.

O questionário na versão original deve ser autoadministrado para excluir viés do examinador, sendo sugerida pelos autores a manutenção desse modelo no questionário traduzido. O tempo médio para responder ao instrumento foi de 20 minutos.

\section{CONCLUSÃO}

O questionário de Freedman e Bernstein encontra-se traduzido e adaptado culturalmente para a língua portuguesa, tendo como título em português Exame de Competência Básica em Medicina Musculoesquelética. Uma validação preliminar do conteúdo foi estabelecida, recomendando-se seu uso para a avaliação do ensino das desordens musculoesqueléticas nas escolas de Medicina do País, possibilitando uma comparação do currículo ortopédico com os padrões internacionais.

\section{REFERÊNCIAS}

1. Godoi, D. Dor musculoesquelética na Atenção Primária à Saúde: um estudo de prevalência em Florianópolis. Revista de Saúde Pública de Florianópolis 2016;1:23-30.

2. Gusso, GDF. Diagnóstico de demanda em Florianópolis utilizando a classificação internacional de Atenção primária: 2a edição (CIAP-2). São Paulo; 2009. Doutorado [Dissertação] - Faculdade de Medicina da Universidade de São Paulo.

3. Irwin M, Symmons D, Allison T, Brammah T, Busby H, Roxby $\mathrm{M}$ et al. Estimating the burden of musculoskeletal disorders in the community: the comparative prevalence of symptoms at different anatomical sites, and the relation to social deprivation. Ann Rheum Dis 1998;57:649-655.

4. Picavet HS, Schouten JS. Musculoskeletal pain in the Netherlands: prevalences, consequences and risk groups, the DMC3-study. Pain 2003;102:167-178

5. Lidgren L. The bone and joint decade 2000-2010. Bull World Health Organ. 2003;81:629

6. Camargo, OP. O ensino da ortopedia nas escolas médicas do Brasil.Revista Brasileira de Ortopedia, 2010;45(2):0-0

7. Freedman KB, Bernstein J. The adequacy of medical school education in musculoskeletal medicine. J Bone Joint Surg [Am] 1998;80-A:1421-27

8. Matzkin E, Smith EL, Freccero D, Richardson AB. Adequacy of education in musculoskeletal medicine. J Bone Joint Surg Am. 2005;87:310-4

9. Jones JK. An evaluation of medical school education in musculoskeletal medicine at the University of the West Indies, Barbados.The West Indian Medical Journal. 2001;50(1):66-68.

10. Menon J, Patro DK. Undergraduate orthopedic education: Is it adequate? Indian Journal of Orthopaedics. 2009;43(1), 82-86.

11. Day CS, Yeh AC, Franko O, Ramirez M, Krupat E. Musculoskeletal medicine: An assessment of the attitudes and knowledge of medical students at Harvard medical school. Acad Med. 2007;82:452-7.

12. Broadhurst N. Measuring cognitive and clinical competency in orthopaedics. J Bone Joint Surg Am. 2002;84:683-4.

13. Beaton DE, Bombardier C, Guillemin F, Ferraz MB. Guidelines for the process of cross-cultural adaptation of self-report measures. Spine (Phila Pa 1976). 2000;25:3186-91.

14. Guillemin F, Bombardier C, Beaton D. Cross-cultural adaptation of health related quality of life measures: literature review and proposed guidelines. J Clin Epidemiol. 1993;46:1417-32. 
15. Aquino V, Falcon S, Neves L, Sendín R. Tradução e adaptação cultural para a língua portuguesa do questionário scoring of patellofemoral disorders: estudo preliminar. Acta ortop. bras. 2011;19(5):273-279.

16. Rubio JS, Iglésias FP, Delgado PG, Santos HM, Martínez MF. Adaptação intercultural para português europeu do questionário "Conocimiento del Paciente sobre sus Medicamentos" (CPM-ES-ES). Cien Saude Colet 2013; 18(12):3633-3644.

17. Beaton D, Bombardier C, Guillemin F, Ferraz MB. Recommendations for the Cross- Cultural Adaptation of the DASH \& Quick DASH Outcome Measures. American Academy of Orthopaedic Surgeons and Institute for Work \& Health [on line]; 2007; 3-13. [capturado em 22fev. 2018]; Disponível em: http:/ /dash.iwh.on.ca/sites/dash/files/ downloads/cross_cultural_adaptation_2007.pdf

18. Nammari SSA, James BK, Ramachandran M. The inadequacy of musculoskeletal knowledge after foundation training in the United Kingdom. J Bone Joint Surg Br. 2009; 91(11): 1413-18.

\section{ANEXO 1 - QUESTIONÁRIO FINAL}

\section{Exame de Competência Básica em Medicina Musculoesquelética}

1. Para qual problema comum se devem examinar todos os recém-nascidos?

2. O que é síndrome compartimental?

3. Artrite séptica aguda do joelho pode ser diferenciada de artrite inflamatória por meio de qual teste laboratorial?

4. Um paciente deslocou seu joelho em um acidente de carro. Qual(is) estrutura(s) corre(m) risco de lesão e deve(m), portanto, ser avaliada(s)?

5. Um paciente atinge seu companheiro com um soco na face e sofre fratura do $5^{\circ}$ metacarpo e uma ruptura de 3 mm na pele sobre a fratura. Qual é o tratamento correto e por quê?

6. Um paciente chega ao consultório reclamando de lombalgia que o acorda durante o sono. Quais dois diagnósticos o preocupam?

7. Como é o tratamento da síndrome compartimental?

8. Um paciente cai apoiado em sua mão e apresenta dor à palpação na tabaqueira anatômica (o espaço entre o extensor longo do polegar e os tendões abdutores). As radiografias iniciais não mostram fratura. Qual diagnóstico deve ser considerado?

9. Um homem de 25 anos se envolve em um acidente automobilístico. Seu membro inferior esquerdo está em posição de flexão do joelho e quadril, com rotação interna e adução do quadril. Qual é o diagnóstico mais provável?

10. Qual nervo é comprimido na síndrome do túnel de carpo?

11. Um paciente tem uma hérnia de disco comprimindo a raiz do $5^{\circ}$ nervo lombar. Como é testada a função motora da raiz do $5^{\circ}$ nervo lombar?

12. Como é testada a função motora do nervo mediano na mão?

13. Um garoto de 12 anos torce severamente seu tornozelo. As radiografias mostram apenas inchaço dos tecidos moles. Apresenta dor no terço distal da fíbula. Quais são dois possíveis diagnósticos?

14. Um paciente apresenta uma nova ocorrência de lombalgia. Em quais condições radiografias simples são indicadas? Favor citar cinco (por exemplo: histórico de trauma).

15. Um paciente tem uma fratura com desvio próximo ao colo da fíbula. Qual estrutura está sob risco de lesão?

16. Um jovem de 20 anos machucou seu joelho jogando futebol. Você o vê no mesmo dia e ele tem uma efusão do joelho. Uma aspiração mostra presença de sangue. Quais são os três diagnósticos mais comuns?

17. Quais são as cinco fontes de metástases ósseas mais comuns?

18. Cite duas diferenças entre artrite reumatoide e osteoartrose.

19. Qual malignidade pode estar presente no osso, mas, tipicamente, não é detectada em uma varredura óssea?

20. Qual é a função do ligamento cruzado anterior normal no joelho?

21. Qual a diferença entre osteoporose e osteomalácia?

22. Em pacientes idosos, fraturas deslocadas do colo do fêmur são tipicamente tratadas com substituição articular, enquanto as fraturas próximas ao trocanter são tratadas com placas e parafusos. Por quê?

23. Qual(is) músculo(s) está(ão) envolvido(s) na epicondilite lateral (cotovelo de tenista)?

24. A ruptura do bíceps no cotovelo resulta em fraqueza tanto da flexão do cotovelo quanto de?

25. Qual(is) músculo(s) realiza(m) a rotação externa do úmero com o braço na lateral? 


\section{ANEXO 2 - RESPOSTAS PONTUADAS NO QUESTIONÁRIO}

1. Displasia congênita do quadril (LCQ, luxação, subluxação também aceitos): 1 ponto

2. Aumento da pressão em um compartimento fascial fechado: 1 ponto

3. Qualquer análise do fluido aspirado (contagem celular, Gram, cultura): 1 ponto

4. Deve mencionar artéria poplítea: 1 ponto

5. Irrigação e desbridamento; risco de infecção: 0,5 ponto cada

6. Tumor e infecção: 0,5 ponto cada

7. Fasciotomia (cirurgia também aceita): 1 ponto

8. Fratura do escafoide (fratura carpal também aceita)

9. Luxação do quadril: 1 ponto

10. Nervo mediano: 1 ponto

11. Dorsiflexão do hálux (extensor dos dedos também aceito): 1 ponto

12. Qualquer função do nervo mediano (flexão metacarpofalangiana; oposição, flexão ou abdução do polegar): 1 ponto

13. Lesão ligamentar e fratura de Salter-Harris I (entorse, fratura também aceitos): 0,5 ponto cada

14. Idade > 50 anos; déficits neurológicos; alterações do controle urinário ou evacuatório; histórico de câncer, gestação, uso de drogas ou esteroides; manifestações sistêmicas (dor noturna, febre); população pediátrica: 0,25 ponto cada, pontuação total se quatro respostas estiverem corretas

15. Nervo fibular comum (nervo fibular também aceito): 1 ponto

16. Ruptura ligamentar, fratura, lesão meniscal periférica (ruptura capsular, luxação da patela também aceitas): 0,5 ponto cada, pontuação total se duas respostas estiverem corretas

17. Mama, próstata, pulmão, rim, tireoide: 0,25 ponto cada, pontuação total se quatro respostas estiverem corretas

18. Quaisquer duas afirmações corretas (i.e., inflamatória vs. degenerativa, articulação interfalangiana proximal vs. articulação interfalangiana distal, etc.): 0,5 ponto cada

19. Mieloma (pontuação total para malignidades hematológicas - leucemia, linfoma): 1 ponto

20. Impedir o deslocamento anterior da tíbia sobre o fêmur fixo: 1 ponto

21. Osteoporose: diminuição na densidade óssea; osteomalácia: diminuição na mineralização óssea (qualquer afirmação correta sobre epidemiologia; fisiopatologia, e.g. estrogênio vs. vitamina $\mathrm{D}$, também aceitas): 1 ponto

22. Suprimento sanguíneo da cabeça do fêmur (necrose avascular, não união também aceitas): 1 ponto

23. Extensores do punho (pontuação total para qualquer extensor do punho - extensor radial curto do carpo, extensor radial longo do carpo, extensor dos dedos): 1 ponto

24. Supinação: 1 ponto

25. Infraespinhal ou redondo menor (pontuação total para manguito rotador): 1 ponto

\section{CONTRIBUIÇÃO DOS AUTORES}

Lucas Augusto Carvalho Raso participou do planejamento do estudo, coleta e análise dos dados, além da elaboração da versão em português do instrumento. Foi o responsável pela redação da primeira versão do artigo. Ubiratan Brum de Castro participou do planejamento do estudo, coleta e análise dos dados, além da elaboração da versão em português do instrumento. Reviu as sucessivas versões do artigo até a aceitação para publicação.

\section{CONFLITO DE INTERESSES}

Os autores declaram não haver conflito de interesses.

\section{ENDEREÇO PARA CORRESPONDÊNCIA}

Av. Prof. Alfredo Balena, 190 - sala 193 / Belo Horizonte - MG. CEP: $30130-100$

Telefone: +55 3134099757

Email: lucasraso@hotmail.com 